\title{
KERAGAAN USAHA PENGGEMUKAN SAPI POTONG DI KABUPATEN CIAMIS
}

\section{THE PERFORMANCE OF BEEF CATTLE FATTENING IN CIAMIS DISTRICT}

\author{
Agus Yuniawan Isyanto*, Sudrajat \\ Fakultas Pertanian Universitas Galuh Ciamis \\ Jl. R.E. Martadinata No. 150 Ciamis 46275 \\ *Corresponding email: gusyun69@ gmail.com \\ (Diterima 29-09-2018; Disetujui 02-01-2019)
}

\begin{abstract}
ABSTRAK
Usaha penggemukan sapi potong di Kabupaten Ciamis memiliki potensi untuk meningkatkan perekonomian wilayah dan pendapatan peternak. Penelitian dilaksanakan dengan menggunakan studi literatur dengan menggunakan data sekunder yang dianalisis secara deskriptif untuk menggambarkan keragaan usaha penggemukan sapi potong di Kabupaten Ciamis. Hasil penelitian menunjukkan bahwa usaha penggemukan sapi potong di Kabupaten Ciamis perlu dikembangkan melalui peningkatan produksi, produktivitas dan efisiensi yang didukung dengan kebijakan pemerintah.
\end{abstract}

Kata kunci: Produksi, produktivitas, efisiensi, sapi potong

\section{ABSTRACT}

The beef cattle fattening farming in Ciamis Distrcit has the potential to increase regional economy and farmer income. The study was carried out using literature studies using secondary data which was analyzed descriptively to describe the performance of beef cattle fattening farming in Ciamis District. The results showed that beef cattle fattening farming in Ciamis District needed to be developed through increased production, productivity and efficiency supported by government policies.

Keywords: Production, productivity, efficiency, beef cattle

\section{PENDAHULUAN}

Semakin baiknya kesadaran
masyarakat akan pentingnya gizi yang
seimbang, pertambahan penduduk, dan
meningkatnya daya beli masyarakat
(Mayulu, dkk., 2010) menyebabkan peningkatan konsumsi daging sapi dengan rata-rata peningkatan sebesar 11,07\% per tahun (Hastuti dan Awami, 2017). Peningkatan kebutuhan terhadap daging sapi tersebut belum bisa dipenuhi secara optimal karena kemampuan produksi daging sapi dalam negeri yang rendah ditinjau dari berbagai keterbatasan, yaitu ketersediaan pakan terutama pada musim kemarau, manajemen budidaya ternak sapi potong yang masih tradisional, kelembagaan peternak yang belum berfungsi secara optimal, dan terjadinya pergeseran fungsi lahan garapan sebagai sumber pakan ternak ruminansia (Wiyatna, dkk., 2012). 
Program swasembada daging sapi telah dicanangkan pemerintah sejak tahun 2005, namun sampai saat ini belum tercapai dengan berbagai permasalahan yang dihadapi. Salah satu alternatif untuk memenuhi kebutuhan terhadap konsumsi daging sapi nasional adalah melalui impor (Widiati, 2014). Kebutuhan daging sapi di Indonesia saat ini dipasok dari tiga pemasok, yaitu peternak rakyat, industri peternakan rakyat dan impor daging sapi (Siregar, 2012). Lebih dari 90\% pasokan daging sapi lokal berasal dari peternakan rakyat yang memiliki skala usaha kecil (Widiati, 2014; Rusdiana, dkk., 2016).

Sistem pemeliharaan sapi potong di Indonesia dibedakan menjadi tiga, yaitu intensif, ekstensif, dan usaha campuran (mixed farming) (Suryana, 2009). Pola pemeliharaan ternak di Indonesia didominasi oleh usaha peternakan berskala kecil dengan karakteristik rendahnya kepemilikan ternak, ternak digunakan sebagai tabungan hidup, ternak dipelihara dalam pemukiman padat penduduk dan dikandangkan di belakang rumah, terbatasnya lahan pemeliharaan, usaha beternak dilakukan secara turun temurun, dan pola bagi hasil jika peternak memiliki kendala permodalan (LPPM, 2015 dalam Zakiah, 2017).
Tujuan peternak dalam memelihara sapi potong adalah untuk mendapatkan keuntungan, sebagai tabungan yang sewaktu-waktu dapat dijual apabila membutuhkan uang, memanfaatkan kotoran ternaknya sebagai pupuk bagi kegiatan usahataninya (Mulyo, dkk., 2012), dan dipelihara sebagai tenaga kerja untuk mengolah lahan usahatani (Suryana, 2009). Usaha ternak merupakan usaha yang mampu mereka geluti setelah menjadi petani karena merupakan usaha turun temurun (Hastuti dan Awami, 2017), namun modal masih menjadi kendala utama dalam upaya peningkatan skala usaha peternakan sapi potong (Mayangsari, dkk., 2014: Sodiq dan Hidayat, 2014).

Terdapat beberapa faktor yang mempengaruhi usaha penggemukan sapi, diantaranya adalah umur, kondisi tubuh dan bobot badan sapi pada saat awal penggemukan, jenis kelamin, bangsa dan mutu pakan. Pemberian pakan pada ternak sapi juga harus sesuai dengan kebutuhan nutrisi sapi potong dengan melihat status fisiologis ternak sapi (Mayangsari, dkk., 2014).

Isu penting dalam pengembangan usaha ternak sapi potong adalah kecenderungan penurunan populasi ternak, rendahnya produktivitas dan 
kompleksnya permasalahan dalam sistem usaha ternak sapi potong. Salah satu solusi yang dapat dilakukan adalah mengintegrasikan usaha ternak sapi potong dengan sumber pakan (Mayulu, dkk., 2010) melalui pemanfaatan sumberdaya lahan dan pakan (limbah pertanian dan perkebunan) yang tersedia secara lokal (Mulyo, dkk., 2012). Indonesia memiliki iklim, topografi, agroekosistem dan ekologi yang dapat mendukung pengembangan peternakan sapi potong terutama dalam penyediaan pakan untuk ternak (Rusdiana, dkk., 2016).

Usaha budidaya ternak sapi potong pada suatu wilayah harus mempertimbangkan kesesuaian lahan, ketersediaan hijauan pakan ternak, limbah dari hasil pertanian, sumberdaya manusia, dan kelestarian yang dilandasi pemahaman mendasar tentang sifat, karakteristik alami lahan dan perilaku ternak (Atmiyati, 2006 dalam Suhaema, dkk., 2014).

Keberhasilan pengembangan usaha ternak sapi potong ditentukan oleh dukungan kebijakan yang strategis yang mencakup tiga dimensi utama agribisnis, yaitu kebijakan pasar input, budidaya, serta pemasaran dan perdagangan dengan melibatkan pemerintah, swasta, dan masyarakat peternak. Dari ketiga dimensi tersebut, kebijakan pemasaran (perdagangan) memegang peranan kunci. Keberhasilan kebijakan pasar output akan berdampak langsung terhadap bagian harga dan pendapatan yang diterima pelaku agribisnis. Kondisi ini akan memantapkan proses adopsi teknologi, peningkatan produktivitas, dan pada akhirnya menjamin keberlanjutan investasi (Mayulu, dkk., 2010).

\section{METODE PENELITIAN}

Penelitian dilaksananakan dengan menggunakan studi literatur). Menurut Nazir (2005), studi literatur selain dimaksudkan untuk mencari sumber data sekunder yang mendukung kegiatan penelitian, juga dimaksudkan untuk mengetahui sampai sejauh mana ilmu yang berhubungan dengan penelitian yang dilaksanakan telah berkembang, serta sampai sejauh mana kesimpulan dan generalisasi dari penelitian sebelumnya yang pernah dibuat sehingga situasi yang diperlukan dapat diperoleh.

Data yang digunakan berupa data sekunder yang diperoleh melalui penelusuran literatur yang terkait dengan penelitian. Data yang diperoleh dianalisis secara deskriptif untuk menggambarkan 
keragaan usaha penggemukan sapi potong di Kabupaten Ciamis.

\section{HASIL DAN PEMBAHASAN}

Analisis Komoditas Unggulan

Analisis pembangunan ekonomi wilayah Kabupaten Ciamis berbasis komoditas peternakan didekati dengan menggunakan analisis Location Quotient (LQ) dengan menggunakan data populasi ternak sebagai dasar analisis. Berdasarkan nilai LQ tersebut dapat diketahui wilayah di Kabupaten Ciamis yang memiliki potensi untuk pengembangan ternak sapi potong sebagaimana terlihat pada Tabel 1 .

Tabel 1. Nilai L/Q Untuk Komoditas Ternak Sapi Potong

\begin{tabular}{ccl}
\hline No & Nilai L/Q & \multicolumn{3}{c}{ Kecamatan } \\
\hline 1 & $\geq 1$ & $\begin{array}{l}\text { Banjarsari, Lakbok, Pamarican, Cidolog, Cijeungjing, Cisaga, Tambaksari. Rancah, } \\
\text { Sukadana, Ciamis, Cikoneng, Sadananya, Panawangan, Panjalu, Baregbeg, } \\
\end{array}$ \\
\hline 2 & $<1$ & $\begin{array}{l}\text { Sukamantri } \\
\text { Cimaragas, Rajadesa, Cihaurbeuti, Cipaku, Jatinagara, Kawali, Panumbangan, } \\
\text { Sindangkasih, Lumbung, Purwadadi }\end{array}$ \\
\hline
\end{tabular}

Sumber: Isyanto, dkk., 2018

Tabel 1 menunjukkan bahwa kecamatan yang merupakan daerah basis untuk komoditas ternak sapi potong adalah kecamatan Banjarsari, Lakbok, Pamarican, Cidolog, Cijeungjing, Cisaga, Tambaksari. Rancah, Sukadana, Ciamis, Cikoneng, Sadananya, Panawangan, Panjalu, Baregbeg, Sukamantri.

Seluruh kecamatan ini telah dapat memenuhi kebutuhannya sendiri terhadap komoditas ternak sapi potong, dan bahkan dapat mengekspor komoditas tersebut ke kecamatan lain atau bahkan ke luar wilayah Kabupaten Ciamis.

\section{Populasi Sapi Potong}

Penelitian Isyanto dan Sugianto (2016) menunjukkan bahwa populasi sapi potong di Kabupaten Ciamis dipengaruhi oleh jumlah pemasukan, pengeluaran dan pemotongan ternak. Selama kurun waktu 2002-2012, rata-rata peningkatan populasi sapi potong sebesar $5,77 \%$ per tahun, rata-rata peningkatan pemasukan sapi potong ke Kabupaten Ciamis sebesar $31,80 \%$ per tahun, dan rata-rata pengeluaran sapi potong sebesar $1,47 \%$ per tahun. Data ini menunjukkan bahwa peningkatan populasi sapi potong di Kabupaten Ciamis lebih banyak ditentukan oleh pemasukan sapi potong dibandingkan dengan pengeluaran sapi potong dan pemotongan ternak. Dengan kata lain, produksi sapi potong di Kabupaten Ciamis belum dapat memenuhi kebutuhan penduduk sehingga perlu didatangkan dari luar. Pertumbuhan populasi, pemasukan, pengeluaran dan 
pemotongan ternak sapi potong tersaji pada Gambar 1.

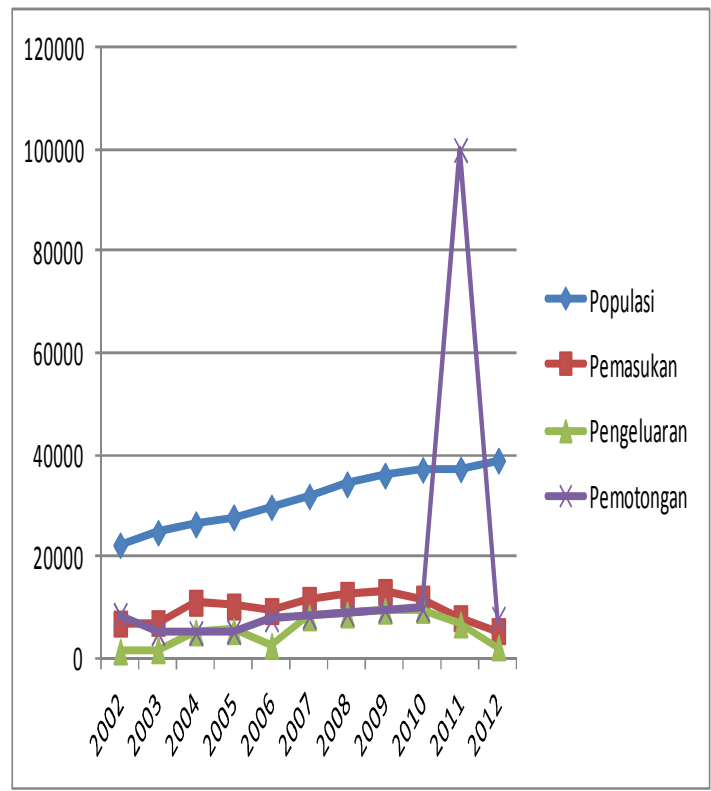

Gambar 1. Pertumbuhan Populasi, Pemasukan, Pengeluaran dan Pemotongan

Faktor-faktor yang berpengaruh terhadap populasi sapi potong di Kabupaten Ciamis adalah pemasukan sapi potong, pengeluaran sapi potong, kebun rumput, lahan pengangonan, lahan hutan, jumlah kepemilikan ternak, populasi penduduk dan harga daging sapi. Hasil analisis yang menunjukkan bahwa jumlah peternak tidak berpengaruh signifikan terhadap populasi sapi potong mengindikasikan bahwa upaya peningkatan populasi sapi potong di Kabupaten Ciamis tidak dilakukan dengan penambahan jumlah peternak, namun dilakukan dengan peningkatan jumlah kepemilikan sapi potong per peternak. Selain itu, ditunjang juga dengan peningkatan ketersediaan rumput unggul sebagai pakan ternak melalui perluasan lahan pengangonan dan pemanfaatan lahan hutan sebagai tempat budidaya rumput hijaaun pakan ternak (Isyanto dan Sugianto, 2016).

Penelitian Isyanto, dkk (201) di Kabupaten Blora menunjukkan bahwa populasi ternak sapi potong dipengaruhi oleh jumlah penduduk, Pendapatan Domestik Regional Bruto (PDRB), PDRB per kapita dan inflasi tahunan.

Pemasukan, pengeluaran dan pemotongan ternak sapi potong ditujukan untuk memenuhi permintaan penduduk Kabupaten Ciamis terhadap daging sapi. Hasil penelitian Isyanto dan Sudrajat (2017) menunjukkan bahwa permintaan daging sapi di Kabupaten Ciamis dipengaruhi oleh harga daging sapi, harga daging ayam, populasi sapi potong tahun sebelumnya, curah hujan, pengeluaran sapi potong, jumlah pemotongan dan jumlah peternak sapi potong berpengaruh signifikan terhadap penawaran daging sapi. Sedangkan produksi daging sapi tahun sebelumnya dan pemasukan sapi potong tidak berpengaruh signifikan terhadap penawaran daging sapi. 


\section{Kepemilikan Ternak Sapi Potong}

Peternak di Kabupaten Ciamis memiliki ternak sapi potong berkisar 1-3 ekor per peternak (Isyanto, 2015). Beberapa penelitian menunjukkan bahwa skala usaha penggemukan sapi potong relatif kecil dengan jumlah sapi yang dipelihara rata-rata 2-3 ekor per peternak (Afriani, dkk., 2014; Hastuti dan Awami, 2017) maupun 3 ekor per peternak (Jan, dkk., 2015; Rouf dan Munawaroh, 2016).

Kendala yang dihadapi oleh peternak di Kabupaten Ciamis dalam upaya meningkatkan jumlah kepemilikan ternak sapi potong adalah: (1) Kendala modal yang menyebabkan peternak tidak memiliki kecukupan modal untuk meningkatkan jumlah kepemilikan ternaknya, (2) Keterbatasan tenaga kerja keluarga dalam proses pemeliharaan ternak, (3) Peternak tidak memiliki kebun rumput sendiri sehingga tergantung kepada ketersediaan rumput di lapangan. Kondisi ini menyebabkan peternak mengalami kesulitan dalam mencari rumput khususnya pada saat musim kemarau, sehingga peternak menempuh jarak yang semakin jauh dari lokasi kandang untuk mencari rumput. Menurut Tribudi dan Ristyawan (2017), rendahnya kepemilikan modal dan kurangnya akses terhadap sumber permodalan masih menjadi kendala bagi peternak dalam melaksanakan usaha ternaknya.

Usaha penggemukan sapi potong di Kabupaten Ciamis 100\% merupakan usaha sampingan (Isyanto, 2015). Penelitian lain menunjukkan bahwa usaha penggemukan sapi potong dijadikan sebagai usaha sampingan oleh $63,33 \%$ peternak (Indrayani, dkk., 2012), 66,67\% petenak (Tribudi dan Ristyawan, 2017), 83,33\% peternak (Mulyo, dkk., 2012), 92\% peternak (Mayangsari, dkk., 2014).

Peternak yang menjadikan usaha penggemukan sapi potong sebagai usaha utama relatif lebih efisien dibandingkan dengan peternak yang menjadikan usahanya tersebut sebagai sampingan. Usaha utama membutuhkan perhatian yang lebih tinggi dan harapan hasil yang lebih besar karena usaha tersebut merupakan sumber penghasilan utama untuk mencukupi kebutuhan keluarganya (Indrayani, dkk., 2012).

Jumlah kepemilikan ternak sapi potong berkaitan dengan kemampuan peternak dalam memelihara ternak dan curahan waktu kerja. Hasil penelitian Isyanto dan Dehen (2015) menunjukkan bahwa kemampuan pemeliharaan ternak sapi potong dipengaruhi oleh tenaga kerja keluarga, curahan waktu kerja, umur, 
pendidikan, kredit, bimbingan teknis dan keanggotaan dalam kelompok.

$$
\text { Penelitian Isyanto }
$$

menunjukkan bahwa curahan waktu kerja peternak pada usaha penggemukan sapi potong berkisar antara 2,14-5,10 $\mathrm{jam} / \mathrm{hari}$, dengan rata-rata 3,65 jam/hari. Jumlah kepemilikan ternak dan pekerjaan utama berpengaruh positif dan signifikan terhadap curahan waktu kerja (Isyanto, 2015). Penelitian Rouf dan Munawaroh (2016) menunjukkan bahwa curahan waktu kerja peternak dalam memelihara sapi potong adalah 31,8 hari orang kerja (HOK) per ekor per 4,1 bulan periode pemeliharaan.

\section{Produktivitas}

Salah satu penyebab kegagalan petani dalam melaksanakan usahatani adalah rendahnya produktivitas sebagai akibat kurangnya efisiensi dalam penggunaan faktor-faktor produksi (Isyanto, 2012)

Produktivitas ternak sapi potong dipengaruhi oleh faktor genetik, pakan dan tatalaksana. Ternak sapi potong yang dipelihara pada peternakan rakyat secara umum mengalami kekurangan pakan karena jumlah pakan yang diberikan biasanya tidak sesuai dengan kebutuhan ternak dan memiliki kualitas yang, serta jarang diberikan pakan tambahan seperti konsentrat (Wiyatna, dkk., 2012).

Penelitian Isyanto (2014) mengenai produktivitas usaha penggemukan sapi potong di Kabupaten Ciamis dengan menggunakan pendekatan produktivitas faktor total (Total Factor Productivity) menunjukkan bahwa produktivitas yang dicapai berkisar 0,2361-1,0000 dengan rata-rata 0,5335 . Peternak yang mencapai produktivitas faktor total di atas rata-rata sebanyak 53 orang, sedangkan yang di bawah rata-rata sebanyak 47 orang.

Pemerintah menetapkan beberapa kebijakan dalam upaya untuk meningkatkan produktivitas, yaitu melalui pengembangan kelembagaan petani peternak, optimalisasi pemanfaatan sumberdaya alam lokal, dan pengembangan teknologi tepat guna (Sodiq dan Budiono, 2012).

\section{Efisiensi Teknis}

Salah satu indikator dari efisiensi adalah jika sejumlah output tertentu dapat dihasilkan dengan menggunakan sejumlah kombinasi input yang lebih sedikit dan dengan kombinasi input-input tertentu dapat meminimumkan biaya produksi tanpa mengurangi output yang dihasilkan. Penggunaan biaya produksi yang minimum akan menghasilkan harga 
output yang lebih kompetitif (Marjaya, 2015).

Beberapa hasil penelitian menunjukkan bahwa faktor-faktor yang berpengaruh terhadap produksi pada usaha penggemukan sapi potong adalah tenaga kerja dan pakan konsentrat (Isyanto, dkk., 2013), pakan konsentrat, dummy umur bakalan, dan dummy pola penguasaan ternak (Indrayani, dkk., 2012), tenaga kerja, pakan hijauan dan bobot bakalan (Rouf dan Munawaroh, 2016).

Peningkatan produksi ternak ruminansia dipengaruhi oleh tiga faktor, yaitu lahan, pakan dan ternak, yang merupakan satu kesatuan organis yang tidak dapat dipisahkan dalam usahatani (Rouf, dkk., 2015).

Efisiensi teknis yang dicapai oleh peternak dalam usaha penggemukan sapi potong berkisar antara 0,54-0,99 dengan rata-rata 0,77 yang menunjukkan adanya peluang untuk meningkatkan produksi sebesar $0,23 \%$ dengan menggunakan input yang ada dan teknologi yang tersedia (Isyanto, dkk., 2013). Penelitian lain menunjukkan tingkat efisiensi teknis yang dicapai oleh peternak berkisar 0,478-0,996 dengan rata-rata 0,764 (Indrayani， dkk., 2012), 0,508-0,974 dengan rata-rata 0,690 (Rouf dan Munawaroh, 2016).

Faktor-faktor yang berpengaruh terhadap inefisiensi teknis adalah pendidikan, pengalaman, jumlah kepemilikan ternak sapi potong, dan akses terhadap kredit (Isyanto, dkk., 2013), umur dan dummy status usaha (Indrayani, dkk., 2012), penyuluhan dan kepemilikan sapi (Rouf dan Munawaroh, 2016).

\section{Analisis Keberlanjutan}

Hasil analisis tentang indeks keberlanjutan masing-masing dimensi (ekologi, ekonomi, sosial budaya, teknologi dan infrastruktur serta kelembagaan) atas dasar selang indeks keberlanjutan disajikan pada Tabel 2.

Tabel 2. Indeks Keberlanjutan Usaha Penggemukan Sapi Potong di Kabupaten Ciamis

\begin{tabular}{clccc}
\hline No. & \multicolumn{1}{c}{ Dimensi } & $\begin{array}{c}\text { Indeks } \\
\text { Keberlanjutan }(\%)\end{array}$ & $\begin{array}{c}\text { Selang Indeks } \\
\text { Keberlanjutan }(\%)\end{array}$ & $\begin{array}{c}\text { Status } \\
\text { Keberlanjutan }\end{array}$ \\
\hline 1 & Ekologi & 69,71 & $50,01-75,00$ & Cukup berkelanjutan \\
\hline 2 & Ekonomi & 63,10 & $50,01-75,00$ & Cukup berkelanjutan \\
\hline 3 & Sosial budaya & 43,93 & $25,01-50,00$ & Kurang berkelanjutan \\
\hline 4 & $\begin{array}{l}\text { Teknologi dan } \\
\text { infrastruktur }\end{array}$ & 11,54 & $00,00-25,00$ & Tidak berkelanjutan \\
\hline 5 & Kelembagaan & 0,00 & $00,00-25,00$ & Tidak berkelanjutan \\
\hline Gabungan/rata-rata & 37,66 & $25,01-50,00$ & Kurang berkelanjutan \\
\hline
\end{tabular}

Sumber: Isyanto dan Dehen, 2015 
Tabel 2 menunjukkan bahwa status masing-masing dimensi mulai dari tidak berkelanjutan hingga cukup berkelanjutan. Dimensi ekologi dan ekonomi menduduki status tertinggi dibandingkan dengan dimensi lainnya dan digolongkan pada status cukup berkelanjutan dengan indeks masing-masing $69,71 \%$ dan $63,10 \%$. Dimensi sosial budaya menduduki status kurang berkelanjutan dengan indeks 43,93\%. Dimensi teknologi dan infrastruktur serta dimensi kelembagaan menduduki tidak berkelanjutan dengan indeks masing-masing $11,54 \%$ dan 0,00\%. Apabila dilihat secara keseluruhan/gabungan, maka dapat disimpulkan bahwa status keberlanjutan usaha penggemukan ternak sapi potong tergolong kurang berkelanjutan dengan $37,66 \%$. Indeks keberlanjutan masingmasing dimensi dapat digambarkan dalam bentuk diagram pancagonal (Gambar 1).Atribut dominan dari dimensi ekologi adalah kebersihan kandang, sedangkan atribut yang cukup dominan adalah pemanfaatan limbah pertanian untuk pakan sapi potong dan ketersediaan Instalasi Pengolahan Air Limbah (IPAL) untuk pengelolaan limbah. Atribut dominan dari dimensi ekonomi adalah ketersediaan infrastruktur atau sarana dan prasarana umum penjualan ternak sapi potong. Atribut dominan dari dimensi sosial budaya adalah frekuensi penyuluhan dan pelatihan sapi potong. Atribut dominan dari dimensi teknologi dan infrastruktur adalah penggunaan vitamin dan probiotik untuk memacu pertumbuhan sapi potong, sedangkan atribut yang cukup dominan adalah ketersediaan infrastruktur atau sarana dan prasarana umum seperti tempat pemotongan dan pemasaran hasil ternak. Tidak ada atribut dominan dari dimensi kelembagaan, namun semua atribut dari dimensi kelembagaan harus menjadi perhatian untuk ditingkatkan (Isyanto dan Dehen, 2015). 


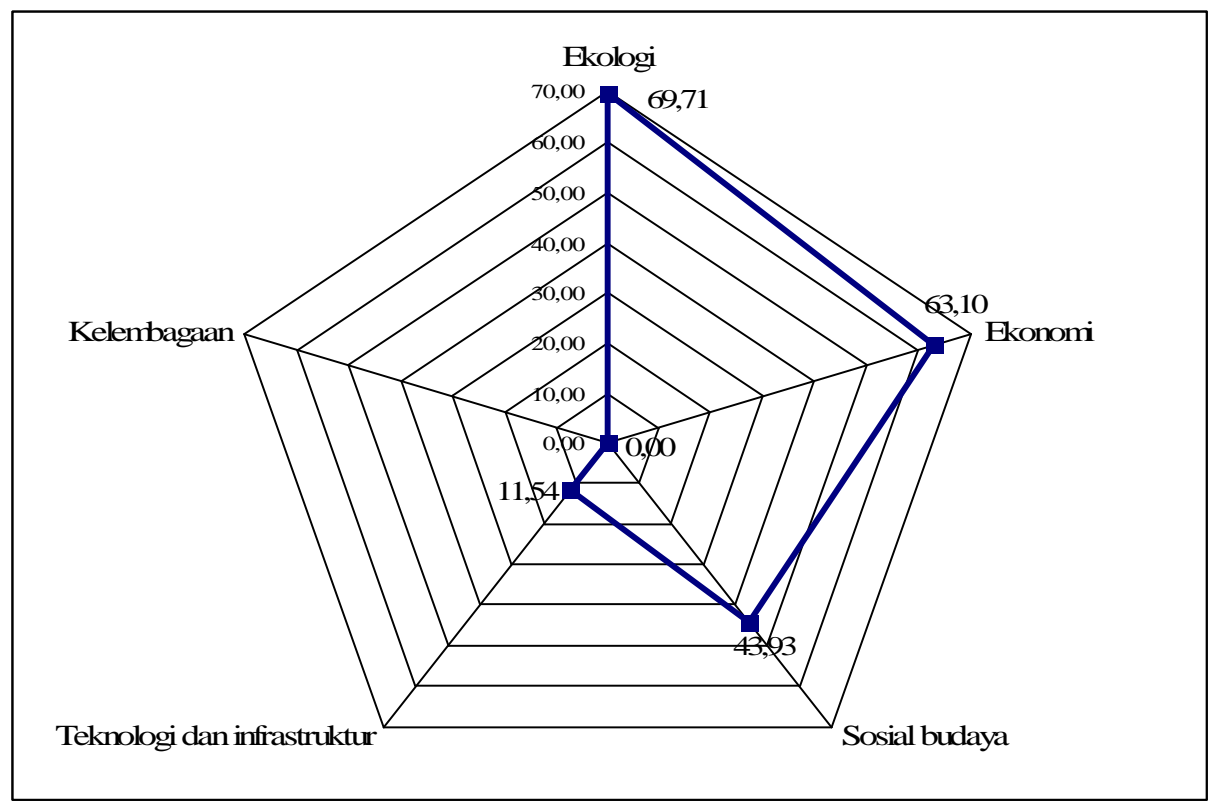

Gambar 2. Diagram Pancagonal Keberlanjutan Usaha Penggemukan Ternak Sapi Potong di Kabupaten Ciamis

\section{KESIMPULAN DAN SARAN}

\section{Kesimpulan}

Kecamatan yang merupakan basis usaha penggemukan ternak sapi potong di Kabupaten Ciamis meliputi kecamatan Banjarsari, Lakbok, Pamarican, Cidolog, Cijeungjing, Cisaga, Tambaksari. Rancah, Sukadana, Ciamis, Cikoneng, Sadananya, Panawangan, Panjalu, Baregbeg, Sukamantri.

Populasi sapi potong di Kabupaten Ciamis dipengaruhi oleh pemasukan sapi potong, pengeluaran sapi potong, kebun rumput, lahan pengangonan, lahan hutan, jumlah kepemilikan ternak, populasi penduduk dan harga daging sapi. Peternak di Kabupaten Ciamis memiliki ternak sapi potong berkisar 1-3 ekor per peternak. Kemampuan pemeliharaan ternak sapi potong dipengaruhi oleh tenaga kerja keluarga, curahan waktu kerja, umur, pendidikan, kredit, bimbingan teknis dan keanggotaan dalam kelompok.

Usaha penggemukan sapi potong di Kabupaten Ciamis $100 \%$ merupakan usaha sampingan. Produktivitas yang dicapai berkisar 0,2361-1,0000 dengan rata-rata 0,5335. Efisiensi teknis yang dicapai berkisar antara 0,54-0,99 dengan rata-rata $\quad 0,77$ Faktor-faktor yang berpengaruh terhadap inefisiensi teknis adalah pendidikan, pengalaman, jumlah kepemilikan ternak sapi potong, dan akses terhadap kredit. 
Saran

Upaya peningkatan populasi sapi potong di Kabupaten Ciamis dapat dilakukan melalui peningkatan jumlah kepemilikan ternak yang ditunjang dengan adanya akses peternak terhadap kredit. Upaya peningkatan produktivitas dan efisiensi dapat dilakukan melalui penyuluhan dan bimbingan teknis. Upaya-upaya tersebut perlu didukung dengan adanya kebijakan pemerintah dalam pengembangan usaha penggemukan sapi potong.

\section{DAFTAR PUSTAKA}

Afriani, H, Idris, N. dan Fatati. 2014. Minat dan Motivasi Peternak Untuk Mengembangkan Ternak Sapi pada Kawasan Perkebunan Kelapa Sawit di Propinsi Jambi. Jurnal Ilmiah Ilmu-Ilmu Peternakan, XVII(2): 77-83.

Hastuti, D. dan Awami, S.N. 2017. Analisis Ekonomi Usahatani Sapi Potong di Kelurahan Plalangan Gunungpati Kota Semarang. Jurnal Ilmiah Cendekia Eksakta, 2(1): 2434.

Indrayani, I., Nurmalina, R. dan Fariyanti, A. 2012. Analisis Efisiensi Teknis Usaha Penggemukan Sapi Potong di Kabupaten Agam Provinsi Sumatera Barat. Jurnal Peternakan Indonesia, 14(1): 286-296.

Isyanto, A.Y. 2012. Faktor-faktor yang Berpengaruh Terhadap Produksi pada Usahatani Padi di Kabupaten Ciamis. Cakrawala Galuh, 1(8): 18.
Isyanto, A.Y. 2014. Kajian Produktivitas Usaha Penggemukan Sapi Potong di Kabupaten Ciamis. Prosiding Seminar Nasional Kedaulatan Pangan dan Pertanian. Jurusan Sosial Ekonomi Pertanian, Fakultas Pertanian, Universitas Gadjah Mada. pp. 559-567.

Isyanto, A.Y. 2015. Faktor-faktor yang Berpengaruh Terhadap Curahan Waktu Kerja pada Usaha Penggemukan Sapi Potong di Kabupaten Ciamis. Mimbar Agribisnis: Jurnal Pemikiran Masyarakat Ilmiah Berwawasan Agribisnis, 1(1): 1-6.

Isyanto, A.Y. dan Dehen, Y.A. 2016. Faktor-faktor yang Berpengaruh Terhadap Kemampuan Pemeliharaan Ternak Sapi Potong di Kabupaten Ciamis. Prosiding Seminar Nasional Hasil Penelitian Pertanian Tahun 2015. Fakultas Pertanian Universitas Gadjah Mada. Pp. 725-730.

Isyanto, A.Y. dan Sudrajat. 2017. Faktorfaktor yang Berpengaruh Terhadap Penawaran Daging Sapi di Kabupaten Ciamis. Prosiding Seminar Nasional Hasil Penelitian Agribisnis I. Program Studi Agribisnis Fakultas Pertanian Universitas Galuh. Pp. 287-293.

Isyanto, A.Y. dan Sugianto, I. 2016. Factors Influencing Population of Beef Cattle in Ciamis Regency, West Java Province, Indonesia. Journal of Economics and Sustainable Development, 7(22): 34-38.

Isyanto, A.Y., dan Dehen, Y.A. 2015. Sustainability Analysis of Beef Cattle Fattening in Ciamis Regency, West Java Province, Indonesia. Journal of Economics and Sustainable Development, 6(20): 148-154. 
Isyanto, A.Y., Semaoen, M.I., Hanani, N. dan Syafrial. 2013. Measurement of Farm Level Efficiency of Beef Cattle Fattening in West Java Province, Indonesia. Journal of Economics and Sustainable Development, 4(10): 100-104.

Isyanto, A.Y., Sudrajat dan Sujaya, D.H. 2018. Pembangunan Ekonomi Wilayah Kabupaten Ciamis Berbasis Komoditas Peternakan. Mimbar Agribisnis: Jurnal Pemikiran Masyarakat Ilmiah Berwawasan Agribisnis, 4(2): 109120

Isyanto, A.Y., Sudrajat, Sujaya, D.H., Ramdan, M. dan Aziz, S. 2018. Faktor-faktor yang Berpengaruh Terhadap Populasi Sapi Potong di Kabupaten Blora Provinsi Jawa Tengah. Prosiding Seminar Nasional Hasil Penelitian Agribisnis II. Program Studi Agribisnis Fakultas Pertanian Universitas Galuh. Pp. 33-37.

Jan, R., Sudrana, I.P. dan Kasip, L.M. 2015. Pengamatan Sifat-sifat yang Mempunyai Nilai Ekonomi Tinggi pada Sapi Bali di Kota Mataram. Jurnal Ilmu dan Teknologi Peternakan Indonesia, 1(1): 53-59.

Marjaya, S. 2015. Analisis Efisiensi dan Daya Saing Komoditas pada Sistem Usahatani Integrasi Jagung-Sapi di Kabupaten Kupang. Ilmu Pertanian, 18(3): 164-174.

Mayangsari, D., Prasetyo, E. dan Mukson. 2014. Evaluasi Kredit Usaha Peternakan Sapi Potong Pada Kelompok Tani Ternak. Jejak, 7(1): 14-21.

Mayangsari, D., Prasetyo, E. dan Mukson. 2014. Evaluasi Program Kredit Usaha Peternakan Sapi Potong pada Tingkat Kelompok Tani Ternak di Kabupaten Grobogan. Jurnal Ilmu Pertanian dan Peternakan, 2(2): 1-7.
Mayulu, H., Sunarso, Sutrisno, C.I. dan Sumarsono. 2010. Kebijakan Pengembangan Peternakan Sapi Potong di Indonesia. Jurnal Litbang Pertanian, 29(1): 34-41.

Mulyo, I.T., Marzuki, S. dan Santoso, S.I. 2012. Analisis Kebijakan Pemerintah Mengenai Budidaya Sapi Potong di Kabupaten Semarang. Animal Agriculture Journal, 1(2): 266-277.

Rauf, A., Priyanto, R. dan Dewi, P. 2015. Produktivitas Sapi Bali pada Sistem Penggembalaan di Kabupaten Bombana. Jurnal Ilmu Produksi dan Teknologi Hasil Peternakan, 03(2): 100-105.

Rouf, A.A. dan Munawaroh, S. 2016. Analisis Efisiensi Teknis dan Faktor Penentu Inefisiensi Usaha Penggemukan Sapi Potong di Kabupaten Gorontalo. Jurnal Pengkajian dan Pengembangan Teknologi Pertanian, 19(2): 103118.

Rusdiana, S., Adiati, U. dan Hutasoit, R. 2016. Analisis Ekonomi Usaha Ternak Sapi Potong Berbasis Agroekosistem Di Indonesia. Jurnal Sosial Ekonomi dan Kebijakan Pertanian Agriekonomika, 5(1) 2016: 137149.

Siregar, G. 2012. Analisis Kelayakan dan Strategi Pengembangan Usaha Ternak Sapi Potong. Agrium, 17(3): 192-201.

Sodiq, A. dan Budiono, M. 2012.Produktivitas Sapi Potong pada Kelompok Tani Ternak di Pedesaan. Agripet, 12(1): 28-33.

Sodiq, A. dan Hidayat, N. 2014. Kinerja dan Perbaikan Sistim Produksi Peternakan Sapi Potong Berbasis Kelompok di Pedesaan. Agripet, 14(1): 56-64.

Suhaema, E., Widiatmaka dan Tjahjono, B. 2014. Pengembangan Wilayah 
Peternakan Sapi Potong Berbasis Kesesuaian Fisik Lingkungan dan Kesesuaian Lahan Untuk Pakan di Kabupaten Cianjur. J. Tanah Lingk., 16(2: 53-60.

Suryana. 2009. Pengembangan Usaha Ternak Sapi Potong Berorientasi Agribisnis Dengan Pola Kemitraan. Jurnal Litbang Pertanian, 28(1): 29-37.

Tribudi, Y.A. dan Ristyawan, M.R. 2017. Analisis Ekonomi Sapi Potong Pola Gaduhan: Studi Kasus di Desa Slorok Kecamatan Kromengan, Kabupaten Malang, Jawa Timur. Jurnal Ekonomi, Bisnis dan Kewirausahaan, 6(1): 30-48.

Widiati, R. 2014. Membangun Industri Peternakan Sapi Potong Rakyat dalam Mendukung Kecukupan Daging Sapi. Wartazoa, 24(4): 191200.
Wiyatna, M.F., Fuah, A.M. dan Mudikdjo, K. 2012. Potensi Pengembangan Usaha Sapi Potong Berbasis Sumber daya Lokal di Kabupaten Sumedang Jawa Barat. Jurnal Ilmu Ternak, 12(2): 16-21.

Wiyatna, M.F., Gurnadi, E. dan Mudikdjo, K. 2012. Produktivitas Sapi Peranakan Ongole pada Peternakan Rakyat di Kabupaten Sumedang. Jurnal Ilmu Ternak, 12(2): 22-25.

Zakiah, Saleh, A. dan Matindas, K. 2017. Gaya Kepemimpinan dan Perilaku Komunikasi GPPT dengan Kapasitas Kelembagaan Sekolah Peternakan Rakyat di Kabupaten Muara Enim. Jurnal Penyuluhan, 13(2): 133-142. 